\title{
USING SCAFFOLDED READING EXPERIENCE (SRE) IN TEACHING READING COMPREHENSION
}

\author{
Herawati \\ UNIVERSITAS MUSI RAWAS \\ Herawatilinggau123@gmail.com
}

\begin{abstract}
A scaffolded reading experience (SRE) is a flexible framework for teaching lessons involving texts. SRE is a set of pre-reading, during reading, and post-reading activities specially designed to assist a particular group of the students in successfully reading, understanding, learning from, and enjoying a particular selection. The study focuses on the effectiveness of using scaffolded reading experience in teaching reading comprehension to the students of the Musi Rawas University? The method used in this research was quasi-experimental method. The population of this study was all of the students of the Musi Rawas University. The sample of this study was second students of Accounting Program Study taken through convenience non random sampling. The data were collected through a written test. It was pre-test and post test. The data analyzed through t-test formula. From this study it was found that the students' pre-test average score in the experimental group was 55 and in the control group was 53.91. Meanwhile the students' post-test average score in the experimental group was 80 and the students' average score in the control group was 75 . In addition of t-obtained were 2.049 where the value of t-table was 1.684 at $\mathrm{df} 74$ in significance level of 0.05 and with one-tailed testing. Since the value of t-obtained was higher than the critical value of the t-table $(2.049>1.684)$, it can be concluded that, teaching reading comprehension by using scaffolded reading experience (SRE) to the students of the Musi Rawas University was effective.
\end{abstract}

Key word: Scaffolded, Reading, Experience

\section{INTRODUCTION}

Reading is one of the four language skills that one needs to master in learning English. According to Cohen (1999:362), Reading is a fundamental learning tool that is practically indispensible both in school and out. Reading is the reader's interaction with a printed message across a range of thinking operations as guided by a purpose for reading. Furthermore, reading is one of the most crucial skills for the children's success in school and life. Based on the Curriculum 2007 competence cited in Ria (2012:1-2), state that the objective of reading is to understand reading text in the form recount, description, narration, 
and news item. The objective is related the students' necessity to face the globalization area. When they have graduated from the school they still can use their reading skill to achieve knowledge.

In fact, the problems were found in reading English correctly. Firstly, students had difficulties understanding the meaning of unfamiliar word and pronounce it. Secondly, they had difficulty to find the main idea in the text. Thirdly, they had difficulty to get the information passages from reading text. Fourth, they had difficulty to find the answer of some questions after reading text whose answers were not available. It means that the students still had problems in comprehending the reading text.

According to Pang (2003:10), reading comprehension is about relating prior knowledge to knowledge contained in written texts. Relating prior knowledge to new knowledge means relate the experience to new knowledge which contained in written text or reading text. Meanwhile According to Miculkecky and Jefries (2007:74) cited in Ria (2012:2), reading Comprehension is more than just recognizing and understanding words. True comprehension means making sense of what you read and connect the ideas in the text to what you already known. So, comprehension means thinking or remembering while you read.

The students' problem in reading comprehension can be solved by using Scaffolded Reading Experience (SRE). Scaffolded Reading Experience (SRE) refers to an approach that assists the learners combine what they know and can do and the intended goal. SRE is a set of pre-reading, during reading, and postreading activities specially designed to assist a particular group of the students in successfully reading, understanding, learning from, and enjoying a particular selection (Graves:1). Here, it was gave temporary supports and guides the learners to participate in a process of free-reading, during reading, and post-reading activities before they can do independently. A successful reading experience was one in which students understood the selection, learned from it, and enjoyed it. 


\section{RESEARCH METHODOLOGY}

The population of this study was all of the students of Musi Rawas University. To conduct this study, quasi-experimental design was used, namely the nonequvalent control group design. Fraenkel and Wallen (1990: 230) state that experimental research is one of the most powerful research methodologies to establish caused and effected relationship between variables.

According to Sugiono (2010:79), The pretest-posttest non-equivalent control group design can be diagrammed as follows:

$\begin{array}{llll}\mathrm{O}_{1} & \mathrm{X} & \mathrm{O}_{2} & \text { (Experimental Group) } \\ \overline{\mathrm{O}_{3}} & & \mathrm{O}_{4} & \text { (Control Group) }\end{array}$

Where:

$\mathrm{O}_{1} \quad$ : Pre-test in the experimental group

X : Treatment to experimental group

$\mathrm{O}_{2} \quad$ : Post-test in the experimental group

: Dashed line indicates non-random assignment to comparison groups

$\mathrm{O}_{3} \quad$ : Pre-test in the control group

$\mathrm{O}_{4} \quad$ : Post-test in the control group

Before the treatment, the pre-test was given to the sample students. Then, the treatment was taught to the samples. After treatment, the post-test which exactly the same as the pre-test was gave to the students.

To collect the data, it was used a written test. Tests measure an individual's knowledge or skill in a given area or subject (Fraenkel, Hyun and Wallen 2012:127). The purpose of this study was to find out the effectiveness of SRE in teaching reading comprehension. The effectiveness of the method would be obtained from the progress shown by the students in reading comprehension. It was known by testing. The test was pre-test and post-test before after treatment. The pre-test was intended to know the students' level of reading comprehension 
skill before the treatment. The post-test was done to measure the students' achievement of all learning task after the treatment. This was done in order to know the students' progress after getting the treatment.

\section{RESULT OF THE STUDY}

\section{The Students' of Scores in the Pre-test of Experimental Group}

The data of the study was collected by the test, pre-test and post-test. In the pre-test of experimental group the students were given written test consisted of 20 questions in form multiple choices, in which the students got 5 point for each the correct answer. To find the students' scores, the students' correct answers were divided with the number of questions and its result were multiplied with the total of standard score. Based on the data, it was found that the highest score was 90 reached by one student and the lowest score was 30 reached by one student. The distribution of the pre-test score in experimental group of the students in reading comprehension presented in Table 6.

TABLE 5

The Students' Scores in the Pre-test of Experimental Group

\begin{tabular}{|l|l|l|l|l|l|}
\hline $\begin{array}{l}\text { Students } \\
\text { Number }\end{array}$ & $\begin{array}{l}\text { Number } \\
\text { of Items }\end{array}$ & $\begin{array}{l}\text { Correct } \\
\text { Answer }\end{array}$ & $\boldsymbol{X}_{\mathbf{1}}$ & $\boldsymbol{X}_{\mathbf{1}}-\overline{\boldsymbol{X}}_{\mathbf{1}}$ & $\left(\boldsymbol{X}_{\mathbf{1}}-\overline{\boldsymbol{X}}_{\mathbf{1}}\right)^{\mathbf{2}}$ \\
\hline 1 & 20 & 11 & 55 & 0 & 0 \\
\hline 2 & 20 & 6 & 30 & -25 & 625 \\
\hline 3 & 20 & 13 & 65 & 10 & 100 \\
\hline 4 & 20 & 8 & 40 & -15 & 225 \\
\hline 5 & 20 & 12 & 60 & 5 & 25 \\
\hline 6 & 20 & 11 & 55 & 0 & 0 \\
\hline 7 & 20 & 18 & 90 & 35 & 1225 \\
\hline 8 & 20 & 10 & 50 & -5 & 25 \\
\hline 9 & 20 & 12 & 60 & 5 & 25 \\
\hline 10 & 20 & 10 & 50 & -5 & 25 \\
\hline 11 & 20 & 12 & 60 & 5 & 25 \\
\hline 12 & 20 & 11 & 55 & 0 & 0 \\
\hline 13 & 20 & 14 & 70 & 15 & 225 \\
\hline 14 & 20 & 7 & 35 & -20 & 400 \\
\hline 15 & 20 & 12 & 60 & 5 & 25 \\
\hline
\end{tabular}




\begin{tabular}{|l|l|l|l|l|l|}
\hline 16 & 20 & 13 & 65 & 10 & 100 \\
\hline 17 & 20 & 11 & 55 & 0 & 0 \\
\hline 18 & 20 & 12 & 60 & 5 & 25 \\
\hline 19 & 20 & 8 & 40 & -15 & 225 \\
\hline 20 & 20 & 10 & 50 & -5 & 25 \\
\hline 21 & 20 & 11 & 55 & 0 & 0 \\
\hline 22 & 20 & 12 & 60 & 5 & 25 \\
\hline 23 & 20 & 11 & 55 & 0 & 0 \\
\hline 24 & 20 & 8 & 40 & -15 & 225 \\
\hline 25 & 20 & 11 & 55 & 0 & 0 \\
\hline 26 & 20 & 10 & 50 & -5 & 25 \\
\hline 27 & 20 & 12 & 60 & 5 & 25 \\
\hline 28 & 20 & 11 & 55 & 0 & 0 \\
\hline 29 & 20 & 10 & 50 & -5 & 25 \\
\hline 30 & 20 & 12 & 60 & 5 & 25 \\
\hline 31 & 20 & 12 & 60 & 5 & 25 \\
\hline 32 & 20 & 11 & 55 & 0 & 0 \\
\hline 33 & 20 & 12 & 60 & 5 & 25 \\
\hline 34 & 20 & 8 & 40 & -15 & 225 \\
\hline 35 & 20 & 11 & 55 & 0 & 0 \\
\hline 36 & 20 & 14 & 70 & 15 & 225 \\
\hline 37 & 20 & 10 & 50 & -5 & 25 \\
\hline Total & & & $\sum \boldsymbol{X}_{\mathbf{1}} \mathbf{2 0 3 5}$ & & $\mathbf{4 2 0 0}$ \\
\hline Average & & & $\mathbf{5 5}$ & & \\
\hline
\end{tabular}

Based on the table, the total score of the students were 2035. To get the mean score of the pre-test in the experimental group, the total score of the students was divided by the total number of the students 20 and the average score was 55 .

Total score $\sum X_{1=} 2035$

$\operatorname{Mean}(\mathrm{X})=\frac{\Sigma X_{1}}{n}$

$X=\frac{2035}{37}=55$

Variance $S_{1}^{2}=\frac{4200}{37-1}$

$S_{1}^{2}=\frac{4200}{36}$

$S_{1}^{2}=116.6$

\section{The Students' Scores in the Pre-test of Control Group}


The data of the study was collected by the test, pre-test and post-test. In the pre-test of control group the students were given written test consisted of 20 questions in form multiple choices, in which the students got 5 point for each the correct answer. To find the students' scores, the students' correct answers were divided with the number of questions and its result were multiplied with the total of standard score. Based on the data, it was found that the highest score was 75 reached by one student. And the lowest score was 30 reached by one student. The distribution of the pre-test score in control group of the students in reading comprehension presented in Table 7.

TABLE 6

The Students' Scores in the Pre-test of Control Group

\begin{tabular}{|l|l|l|l|l|l|}
\hline $\begin{array}{l}\text { Students } \\
\text { Number }\end{array}$ & $\begin{array}{l}\text { Number of } \\
\text { Items }\end{array}$ & $\begin{array}{l}\text { Correct } \\
\text { Answer }\end{array}$ & $\boldsymbol{X}_{\mathbf{2}}$ & $\boldsymbol{X}_{\mathbf{2}}-\overline{\boldsymbol{X}}_{\mathbf{2}}$ & $\left(\boldsymbol{X}_{\mathbf{2}}-\overline{\boldsymbol{X}}_{\mathbf{2}}\right)^{\mathbf{2}}$ \\
\hline 1 & 20 & 10 & 50 & -3.91 & 15.28 \\
\hline 2 & 20 & 9 & 45 & -8.91 & 79.38 \\
\hline 3 & 20 & 11 & 55 & 1.09 & 1.18 \\
\hline 4 & 20 & 8 & 40 & -13.91 & 193.48 \\
\hline 5 & 20 & 10 & 50 & -3.91 & 15.28 \\
\hline 6 & 20 & 12 & 60 & 6.09 & 37.08 \\
\hline 7 & 20 & 11 & 55 & 1.09 & 1.18 \\
\hline 8 & 20 & 12 & 60 & 6.09 & 37.08 \\
\hline 9 & 20 & 14 & 70 & 16.09 & 258.88 \\
\hline 10 & 20 & 8 & 40 & -13.91 & 193.48 \\
\hline 11 & 20 & 15 & 75 & 21.09 & 444.78 \\
\hline 12 & 20 & 10 & 50 & -3.91 & 15.28 \\
\hline 13 & 20 & 12 & 60 & 6.09 & 37.08 \\
\hline 14 & 20 & 9 & 45 & -8.91 & 79.38 \\
\hline 15 & 20 & 10 & 50 & -3.91 & 15.28 \\
\hline 16 & 20 & 10 & 50 & -3.91 & 15.28 \\
\hline 17 & 20 & 12 & 60 & 6.09 & 37.08 \\
\hline 18 & 20 & 11 & 55 & 1.09 & 1.18 \\
\hline 19 & 20 & 8 & 40 & -13.91 & 193.48 \\
\hline 20 & 20 & 12 & 60 & 6.09 & 37.08 \\
\hline 21 & 20 & 10 & 50 & -3.91 & 15.28 \\
\hline 22 & 20 & 6 & 30 & -23.91 & 571.68 \\
\hline 23 & 20 & 13 & 65 & 11.09 & 122.98 \\
\hline 24 & 20 & 10 & 50 & -3.91 & 15.28 \\
\hline 25 & 20 & 11 & 55 & 1.09 & 1.18 \\
\hline & & & & & \\
\hline & 20 & 10 & & \\
\hline & 20 & 10 & & & \\
\hline & 20 & 10 & & & \\
\hline
\end{tabular}




\begin{tabular}{|l|l|l|l|l|l|}
\hline 26 & 20 & 12 & 60 & 6.09 & 37.08 \\
\hline 27 & 20 & 9 & 45 & -8.91 & 79.38 \\
\hline 28 & 20 & 14 & 70 & 16.09 & 258.88 \\
\hline 29 & 20 & 12 & 60 & 6.09 & 37.08 \\
\hline 30 & 20 & 9 & 45 & -8.91 & 79.38 \\
\hline 31 & 20 & 10 & 50 & -3.91 & 15.28 \\
\hline 32 & 20 & 13 & 65 & 11.09 & 122.98 \\
\hline 33 & 20 & 10 & 50 & -3.91 & 15.28 \\
\hline 34 & 20 & 14 & 70 & 16.09 & 258.88 \\
\hline 35 & 20 & 11 & 55 & 1.09 & 1.18 \\
\hline 36 & 20 & 12 & 60 & 6.09 & 37.08 \\
\hline 37 & 20 & 9 & 45 & -8.91 & 79.38 \\
\hline Total & & & $\sum \boldsymbol{X}_{\mathbf{2}} \mathbf{1 9 9 5}$ & & $\mathbf{3 4 5 6 . 4 6}$ \\
\hline Average & & & $\mathbf{5 3 . 9 1}$ & & \\
\hline
\end{tabular}

Based on the table, the total score of the students were 1995. To get the mean score of the pre-test in the control group, the total score of the students was divided by the total number of the students 20 and the average score was 53.91 .

Total score $\sum X_{2}=1995$

$\operatorname{Mean}(X)=\frac{\Sigma X_{2}}{n}$

$X=\frac{1995}{37}$

$\mathbf{X}=\mathbf{5 3 . 9 1}$

Variance $S_{2}^{2}=\frac{\Sigma X_{2}^{2}}{n-1}$

$S_{2}^{2}=\frac{3456.46}{37-1}$

$S_{2}^{2}=\frac{3456.46}{36}$

$S_{2}^{2}=96.0$

It analyzed the pre-test of two samples to find out whether or not they are homogenous. The value of f-table is 1.86 at significance level 0.05 and $\mathrm{df}$ is 37 . If the result of the f-test is same or less than 1.86 the variances can be called 
homogeny. The following table showed the result of the pre-test in the experimental group and control group.

TABLE 7

Table Calculation of Pre-test Result in Experimental Group and Control Group

\begin{tabular}{|l|l|}
\hline Experimental Group & Control Group \\
\hline$\sum X_{1}=2035$ & $\sum X_{1}=1995$ \\
\hline$X_{1}=55$ & $X_{2}=53.91$ \\
\hline$S_{1}^{2}=116.6$ & $S_{2}^{2}=96.0$ \\
\hline$N_{1}=37$ & $N_{1}=37$ \\
\hline
\end{tabular}

To find out the variance of pre-test in the experimental group and control group was homogenous of not, it used F formula (Sugiono, 2011:197).

$\mathrm{F}=\frac{\text { Highest Variance }}{\text { Lowest Variance }}$

$\mathbf{F}=\frac{116.6}{96.0}$

$\mathbf{F}=\mathbf{1 . 2 1}$

After the result above, it found that the result of F-test was 1.21 with $\mathrm{df}=37$ the critical value $f$ the f-table is 1.78 . It means the variance of two group less than the value of f-table $(1.21<1.86)$.

\section{The Student's Scores in the Post-test of Experimental Group}

The data of the study was collected by the test, pre-test and post-test. In the post-test of experimental group the students were given written test consisted of 20 questions in form multiple choices, in which the students got 5 point for each the correct answer. To find the students' scores, the students' correct answers were divided with the number of questions and its result were multiplied with the total of standard score. Based on the data, it was found that the highest score was 100 reached by three students and the lowest score was 60 reached by one student. 
The distribution of the post-test score in experimental group of the students in reading comprehension presented in Table 8.

TABLE 8

The Students' Scores in the post-test of Experimental Group

\begin{tabular}{|c|c|c|c|c|c|}
\hline $\begin{array}{l}\text { Students } \\
\text { Number }\end{array}$ & $\begin{array}{l}\text { Number of } \\
\text { Items }\end{array}$ & $\begin{array}{l}\text { Correct } \\
\text { Answer }\end{array}$ & $X_{1}$ & $X_{1}-\bar{X}_{1}$ & $\left(X_{1}-\bar{X}_{1}\right)^{2}$ \\
\hline 1 & 20 & 18 & 90 & 10 & 100 \\
\hline 2 & 20 & 14 & 70 & -10 & 100 \\
\hline 3 & 20 & 16 & 80 & 0 & 0 \\
\hline 4 & 20 & 14 & 70 & -10 & 100 \\
\hline 5 & 20 & 15 & 75 & -5 & 25 \\
\hline 6 & 20 & 14 & 70 & -10 & 100 \\
\hline 7 & 20 & 16 & 80 & 0 & 0 \\
\hline 8 & 20 & 18 & 90 & 10 & 100 \\
\hline 9 & 20 & 19 & 95 & 15 & 225 \\
\hline 10 & 20 & 13 & 65 & -15 & 225 \\
\hline 11 & 20 & 18 & 90 & 10 & 100 \\
\hline 12 & 20 & 15 & 75 & -5 & 25 \\
\hline 13 & 20 & 20 & 100 & 20 & 400 \\
\hline 14 & 20 & 13 & 65 & -15 & 225 \\
\hline 15 & 20 & 16 & 80 & 0 & 0 \\
\hline 16 & 20 & 15 & 75 & -5 & 25 \\
\hline 17 & 20 & 16 & 80 & 0 & 0 \\
\hline 18 & 20 & 20 & 100 & 20 & 400 \\
\hline 19 & 20 & 14 & 70 & -10 & 100 \\
\hline 20 & 20 & 16 & 80 & 0 & 0 \\
\hline 21 & 20 & 15 & 75 & -5 & 25 \\
\hline 22 & 20 & 13 & 65 & -15 & 225 \\
\hline 23 & 20 & 17 & 85 & 5 & 25 \\
\hline 24 & 20 & 16 & 80 & 0 & 0 \\
\hline 25 & 20 & 18 & 90 & 10 & 100 \\
\hline 26 & 20 & 15 & 75 & -5 & 25 \\
\hline 27 & 20 & 14 & 70 & -10 & 100 \\
\hline 28 & 20 & 15 & 75 & -5 & 25 \\
\hline 29 & 20 & 12 & 60 & 20 & 400 \\
\hline 30 & 20 & 18 & 90 & 10 & 100 \\
\hline 31 & 20 & 17 & 85 & 5 & 25 \\
\hline 32 & 20 & 18 & 90 & 10 & 100 \\
\hline 33 & 20 & 15 & 75 & -5 & 25 \\
\hline 34 & 20 & 14 & 70 & -10 & 100 \\
\hline 35 & 20 & 20 & 100 & 10 & 100 \\
\hline 36 & 20 & 19 & 95 & 15 & 225 \\
\hline
\end{tabular}




\begin{tabular}{|l|l|l|l|l|l|}
\hline 37 & 20 & 16 & 80 & 0 & 0 \\
\hline Total & & & $\sum \boldsymbol{X}_{\mathbf{2}} \mathbf{2 9 6 0}$ & & $\mathbf{3 8 5 0}$ \\
\hline Average & & & $\mathbf{8 0}$ & & \\
\hline
\end{tabular}

Based on the table, the total score of the students were 2960. To get the mean score of the post-test in the experimental group, the total score of the students was divided by the total number of the students 20 and the average score was 80 .

Total score $\sum X_{1}=2960$

$\operatorname{Mean}(\mathrm{X})=\frac{\Sigma X_{1}}{n}$

$X=\frac{2960}{37}$

$\mathbf{X}=\mathbf{8 0}$

Variance $S_{1}^{2}=\frac{\sum X_{1}^{2}}{n-1}$

$S_{1}^{2}=\frac{3850}{37-1}$

$S_{1}^{2}=\frac{3850}{36}$

$S_{1}^{2}=106.94$

\section{The Students' Scores in the Post-test of Control Group}

The data of the study was collected by the test, pre-test and post-test. In the post-test of control group the students were given written test consisted of 20 questions in form multiple choices, in which the students got 5 point for each the correct answer. To find the students' scores, the students' correct answers were divided with the number of questions and its result were multiplied with the total of standard score. Based on the data, it was found that the highest score was 90 reached by five students and the lowest score was 55 reached by three students. The distribution of the post-test score in control group of the students in reading comprehension presented in Table 9. 
TABLE 9

The Students' Scores in the Post-test of Control Group

\begin{tabular}{|l|l|l|l|l|l|}
\hline $\begin{array}{l}\text { Students } \\
\text { Number }\end{array}$ & $\begin{array}{l}\text { Number } \\
\text { of Items }\end{array}$ & $\begin{array}{l}\text { Correct } \\
\text { Answer }\end{array}$ & $\boldsymbol{X}_{\mathbf{2}}$ & $\boldsymbol{X}_{\mathbf{2}}-\overline{\boldsymbol{X}}_{\mathbf{2}}$ & $\left(\boldsymbol{X}_{\mathbf{2}}-\overline{\boldsymbol{X}}_{\mathbf{2}}\right)^{2}$ \\
\hline 1 & 20 & 15 & 75 & 0 & 0 \\
\hline 2 & 20 & 16 & 80 & 5 & 25 \\
\hline 3 & 20 & 12 & 60 & -15 & 225 \\
\hline 4 & 20 & 11 & 55 & -20 & 400 \\
\hline 5 & 20 & 18 & 90 & 15 & 225 \\
\hline 6 & 20 & 13 & 65 & -10 & 100 \\
\hline 7 & 20 & 17 & 85 & 10 & 100 \\
\hline 8 & 20 & 16 & 80 & 5 & 25 \\
\hline 9 & 20 & 18 & 90 & 15 & 225 \\
\hline 10 & 20 & 11 & 55 & -20 & 400 \\
\hline 11 & 20 & 18 & 90 & 15 & 225 \\
\hline 12 & 20 & 15 & 75 & 0 & 0 \\
\hline 13 & 20 & 16 & 80 & 5 & 25 \\
\hline 14 & 20 & 13 & 65 & -10 & 100 \\
\hline 15 & 20 & 14 & 70 & -5 & 25 \\
\hline 16 & 20 & 12 & 60 & -15 & 225 \\
\hline 17 & 20 & 17 & 85 & 10 & 100 \\
\hline 18 & 20 & 15 & 75 & 0 & 0 \\
\hline 19 & 20 & 11 & 55 & -20 & 400 \\
\hline 20 & 20 & 18 & 90 & 15 & 225 \\
\hline 21 & 20 & 16 & 80 & 5 & 25 \\
\hline 22 & 20 & 14 & 70 & -5 & 25 \\
\hline 23 & 20 & 17 & 85 & 10 & 100 \\
\hline 24 & 20 & 12 & 60 & -15 & 225 \\
\hline 25 & 20 & 16 & 80 & 5 & 25 \\
\hline 26 & 20 & 15 & 75 & 0 & 0 \\
\hline 27 & 20 & 13 & 65 & -10 & 100 \\
\hline 28 & 20 & 14 & 70 & -5 & 25 \\
\hline 29 & 20 & 117 & 85 & 10 & 100 \\
\hline 30 & 20 & 18 & 90 & 15 & 225 \\
\hline 31 & 20 & 14 & 70 & -5 & 25 \\
\hline 32 & 20 & 17 & 85 & 10 & 100 \\
\hline 33 & 20 & 15 & 75 & 0 & 0 \\
\hline 34 & 20 & 16 & 80 & 5 & 25 \\
\hline 35 & 14 & 70 & -5 & 25 \\
\hline 36 & 15 & 75 & 0 & 0 \\
\hline 37 & 16 & 80 & 5 & 25 \\
\hline Total & 20 & $2 \boldsymbol{X}_{\mathbf{2}} \mathbf{2 7 7 5}$ & & $\mathbf{4 1 0 0}$ \\
\hline Average & & 75 & & \\
\hline & & & & & \\
\hline
\end{tabular}


Based on the table, the total score of the students were 2775 . To get the mean score of the post-test in the control group, the total score of the students was divided by the total number of the students 20 and the average score was 75 .

Total score $\sum X_{2}=\mathbf{2 7 7 5}$

$\operatorname{Mean}(\mathrm{X})=\frac{\Sigma X_{2}}{n}$

$X_{2}=\frac{2775}{37}$

$X_{2}=75$

Variance $S_{2}^{2}=\frac{\sum S_{2}^{2}}{N-1}$

$S_{2}^{2}=\frac{4100}{37-1}$

$S_{2}^{2}=\frac{4100}{36}$

$S_{2}^{2}=113.88$

\subsubsection{The Calculation of t-test}

After gaining the result of pre-test and the post-test, it started to analyze them by using t-test. The formula of the t-test was written below.

$$
\begin{aligned}
& t=\frac{\bar{X}_{1}-\bar{X}_{2}}{\sqrt{\frac{s_{1}^{2}}{n_{1}}+\frac{s_{2}^{2}}{n_{2}}}} \\
& \mathbf{t}=\frac{80-75}{\sqrt{\frac{106.94}{37}+\frac{113.88}{37}}} \\
& \mathbf{t}=\frac{5}{\sqrt{2.89+3.07}} \\
& \mathbf{t}=\frac{5}{\sqrt{5.96}} \\
& \mathbf{t}=\frac{5}{2.44}
\end{aligned}
$$


$\mathbf{t}=\mathbf{2 . 0 4 9}$

$t_{o b t}>t_{t a b}$

\section{$2.049>1.684$}

In this research, the result of t-obtained was 2.049 where the value of $t$-table was 1.684 at significance level of 0.05 and with one-tailed testing. Since the value of t-obtained was higher than the value of t-table $(2.049>1.684)$, consequently the null hypothesis (Ho) was rejected and the alternative (Ha) was accepted. It means that it was effective to teach reading comprehension by using Scaffolded Reading Experience (SRE) to the students of the Musi Rawas University.

Based on the degree of freedom (df) to numerator and denominator is 37 . In the 0.05 level significance, F-table should exceed 1.86 as its critical value. F-test was smaller than F-table $(1.21<1.86)$. So, variance of pre-test in experimental group and control group was homogeneous. It mean that the students' average ability in reading before used scaffolded reading experience in experimental group and control group used traditional method has same level.

The students' average scores of post-test in experimental group were 80 . The highest score was 100 reached by three students and the lowest score was 60 reached by one students. The students' average scores of post-test in control group were 75 . The highest score was 90 reached by four students and the lowest score was 55 reached by three students. It means there is significance different between the students' post-test in experimental group scores and the post-test in control group scores. The students' scores in the post-test in experimental group were significantly higher than those in the post-test in control group. In other words, the treatment that was given to the students can influence their ability in reading comprehension.

Besides, the t-obtained showed that the alternative hypothesis with 0.05 of significance level was accepted, because the result of the calculation of the independent t-test formula was 2.049, t-obtained was higher than the critical value 
1.684. It means that it was effective to teach reading comprehension by using Scaffolded reading experience to the students of the Musi Rawas University.

\section{CONCLUSIONS}

Based on the findings described in chapter IV, the students' average score of experimental group in post-test was 80 . The students' average score of control group in post-test was 75 . The critical value at 0.05 significance level with df 37 was 1.684 and t-obtained 2.049. It means that t-obtained was higher than $\mathrm{t}$ table 1.684 as critical value. Consequently, the null hypothesis (Ha) was accepted and the alternative hypothesis (Ho) was rejected. It could be concluded that, teaching reading comprehension by using scaffolded reading experience (SRE) to the students of the Musi Rawas University was effective.

\section{REFERENCES}

Amelia. 2008. Using Scaffolded Reading Experience to Improve Reading Comprehension Achievement of the Eleventh Grade Students of SMA Negeri 2 Palembang. Unpublished Undergraduate Thesis. Palembang: Faculty of Teacher Training and Education, Muhamadiyah University Palembang.

Arikunto, Suharsimi, 2010. Prosedur Penelitian Suatu Pendekatan Praktek. Jakarta: PT Rineka Cipta.

Brown, H Douglas. 2007. Principles of English Learning and Teaching. Pearson Education, White Plains, New: San Francisco.

Cohen, Sandra B et al. 1999. Language Arts. Ohio: A Bell \& Howell Company.

Fajarwati, Ria. 2012. Teaching Reading Experience to the Eighth Grade Students of SMP N.4 Muara Sugihan through Fables. Unpublished Undergraduate Thesis. Palembang: Faculty of Teacher Training and Education, Muhamadiyah University Palembang.

Fraenkel, Jack R and Norman E. Wallen. 1990. How to Design and Evaluate Research in Education. New York: McGraw-Hill, Inc.

Fraenkel, Jack R, Helen and Norman E. Wallen. 2012. How to Design and Evaluate Research in Education. New York: McGraw-Hill, Inc.

Graves, M.F. \& Graves, B.B. 2003. Scaffolded Reading Experiences: Designs for Students Success, $2^{\text {nd }}$ Ed. Norwood, MA: Christopher-Gordon. 
http://www.onlinereadingresources.com/sre/SRECha_2.pdf Assessed on 12 December 2012.

Hatch, Evalyn and Hossein Farhadi. 1982. Research Design and Statistic for Applied Lingustics. Los Angles: University of California.

Moore, Kenneth D. 2005. Effective Instructional Strategies. United Stated of America: Sage Publications, Inc.

Pang, Elizabeth S, Angaluki Muaka, Elizabeth B Berdthard, and Michael L, Kamil. 2003. Teaching Reading. France: SADAG Bellegarde.

Sugiono. 2010. Metode Penelitian Pendidikan Kuantitatif, Kualitatif dan R\&D. Bandung: alfabeta.

Sugiono. 2011. Metode Penelitian Kuantitatif, Kualitatif dan R\&D. Bandung: alfabeta.

Snow, Catherine E. 2002. Reading for Understanding Toward an R\&D Program in Reading Comprehension. Santa Monica: RAND.

Vaughn, Sharon Linan Thomson. 2004. Research Based Methods of Reading Instruction, Grades K-3. United States of America: Association for Supervision and Curriculum Development (ASCD). 